\title{
National Identities in Troubled Times: Germany and Southern European Countries after the Great Recession
}

\author{
Antonia María Ruiz Jiménez ${ }^{1, *(\mathbb{D})}$, Nieves Aquino Llinares ${ }^{2}$ and Elena Ferri Fuentevilla ${ }^{3}$ (i) \\ 1 Sociology Department, Faculty of Social Science, Pablo de Olavide University, Ctra. de Utrera Km.1, \\ 41013 Seville, Spain \\ 2 Area of Statistics and IO, Department of Economics, Quantitative Methods and Economic History, \\ Faculty of Experimental Sciences, Pablo de Olavide University, Ctra. de Utrera Km.1, 41013 Seville, Spain; \\ naqulli@upo.es \\ 3 Department of Sociology, Faculty of Political Sciences and Sociology, University of Granada, Calle Rector \\ López Argüeta, s/n, 18001 Granada, Spain; eferfue@ugr.es \\ * Correspondence: amruiz@upo.es
}

Citation: Ruiz Jiménez, Antonia María, Nieves Aquino Llinares, and Elena Ferri Fuentevilla. 2021.

National Identities in Troubled Times: Germany and Southern European Countries after the Great Recession Genealogy 5: 40. https://doi.org/ $10.3390 /$ genealogy5020040

Received: 9 February 2021

Accepted: 7 April 2021

Published: 16 April 2021

Publisher's Note: MDPI stays neutral with regard to jurisdictional claims in published maps and institutional affiliations.

Copyright: (c) 2021 by the authors. Licensee MDPI, Basel, Switzerland. This article is an open access article distributed under the terms and conditions of the Creative Commons Attribution (CC BY) license (https:// creativecommons.org/licenses/by/ $4.0 /)$

\begin{abstract}
This article aims to elucidate the effects of the Great Recession and the retrenchment of welfare on national identity in several European countries. While different authors have observed that good economic performance, redistribution, and the growth of welfare strengthen countries as political communities of solidarity, there is much less empirical evidence regarding the consequences of an economic crisis for national identity. To investigate these consequences, we focus on a set of countries where the 2008 Great Recession resulted in different impacts, namely, Germany and four countries in Southern Europe (Italy, Spain, Portugal, and Greece). We use secondary quantitative data from Eurobarometer surveys to test aggregated and individual hypotheses relating to both the size and direction of the Great Recession's effects on national identity. Our results suggest that the roles and impacts of economic variables may be different depending on the relative economic performance of a country within its own context. It seems easier to confirm that good economic performance, in relative terms, might strengthen national identity than proving that poor economic performance will weaken national identity. Even if no definitive empirical evidence can be given at this point, our data suggest a rationalization or compensation mechanism such that citizens look for where to anchor their strong national identities after they have decided on them. If an economy is performing well, then it would become a good anchorage for holding a strong national identity; however, if an economy is not performing well, then economic factors will cease to be a fundamental element for national identity holders.
\end{abstract}

Keywords: national identity; civic and ethnic identities; ascribed and achieved identities; Great Recession; welfare state; welfare nationalism; Germany; Southern European countries

\section{Introduction}

Different authors have identified the positive connections between national economies and national identities (Rodríguez-Pose and Sandall 2008; Campbell and Hall 2009), in which states, portraying themselves as agents of equitable development, have fostered national identities via ideological legitimation. If good economic performance, redistribution, and, more generally speaking, the growth of welfare strengthen a state as a political community of solidarity, what are the effects of the Great Recession and the retrenchment of welfare?

As stated in different investigations, national identity is as an important mechanism for political stability and cohesion, especially within democratic regimes (Mason 2010; Huddy 2013). While the literature on welfare nationalism has explored the connection between solidarity, social protection, and attachment to the nation, analysis has mainly been performed in positive terms where the connections between economic crises, their 
political consequences, and the process of disentanglement from the nation remain largely unexplored. This article approximates this question by focusing on a particular set of countries where the 2008 Great Recession has had different impacts.

Our cases include Germany and four Southern European countries (Italy, Spain, Portugal, and Greece). These countries have experienced unequal economic shocks with a milder impact and quicker recovery in Germany as compared to Italy, Spain, Portugal, and Greece. As Figure 1 shows, the impact of the crisis on the percentage of GDP growth after 2008 was softer in Germany as compared to the Southern European countries, particularly Greece. These different trends are also observable regarding the GDP in terms of purchasing power parity, where all the five countries followed an increasing trend until approximately 2008. Although Germany suffered a slight decrease then, it soon recovered its growth trend while most of the Southern European countries fell back, increasing their distance from Germany. Again, Greece stands out with the worst situation.

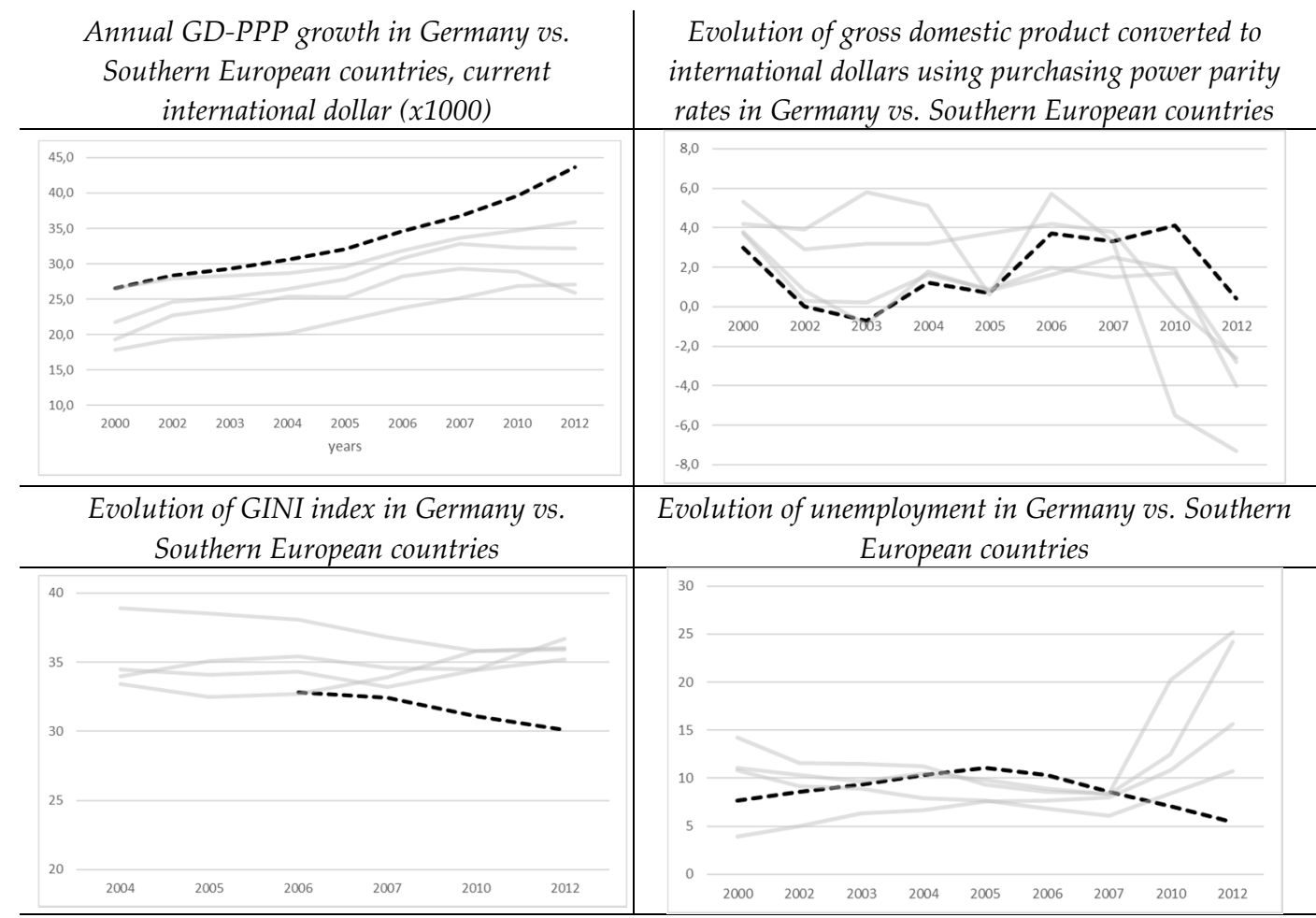

Evolution of the percentage of GDP dedicated to social security transfers in Germany vs. Southern European countries

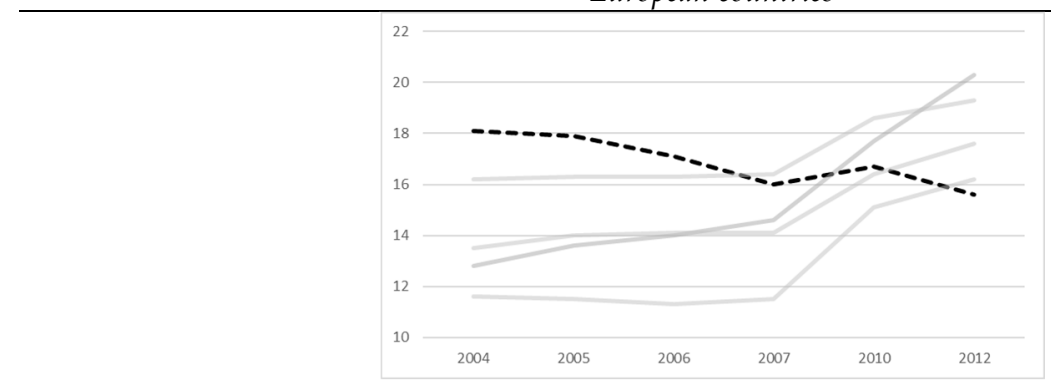

Figure 1. Economic impact of the Great Recession in Germany as compared to the selected Southern European countries (Italy, Spain, Portugal, and Greece).

The data for the Gini index, an indicator of inequality and welfare, show diverging trends among our cases, where Germany is the only country in which inequality decreased over the period. On the contrary, inequality has increased in the remaining four South- 
ern European countries since around 2009, reversing the previous diminishing trends in inequality (except for Spain, where inequality was already growing since 2006).

Unemployment trends clearly distinguish Germany from the selected Southern European countries. These trends show a pronounced increasing trend in the percentage of unemployment linked to the economic crisis, while in Germany, unemployment decreased during the observed period. Among the Southern European countries, the increasing trends are stronger in Greece and Spain as compared to Italy and Portugal. The percentage of GDP dedicated to social transfer shows remarkable similarities to unemployment, as these benefits make up a significant part of the social security transfer budget. The increases have been notable in Southern European countries, while in Germany, there is a decreasing trend (broken only between 2008 and 2009).

At the same time, and partly as a consequence of these economic trends, the Great Recession in Europe has brought in important political consequences: it has destabilized the Western European party system (Hernández and Kriesi 2016), it has eroded support for democracy (Armingeon and Guthmann 2014), it has weakened solidarity among the members of federations (Braun and Trein 2014), and it has increased distrust in political institutions, especially among peripheral countries and for subjects from lower social strata (Dotti Sani and Magistro 2016). In particular, in our five countries, the electoral punishment of traditional parties and support for challenger or niche parties are obvious in the aftermath of the Great Recession (Hobolt and Tilley 2016; Kriesi 2012, 2014; Freire et al. 2014). Notable examples of this include Siriza and Golden Dawn in Greece (Vasilopoulou and Halikiopoulou 2013), Beppe Grillo's M5 in Italy (Baldini 2013; Bordignon and Ceccarini 2013), Podemos in Spain (Cordero and Montero 2015), the contest of the folkloristic candidate Manuel Coelho in the Portuguese presidential elections of 2011 (Kriesi 2012, p. 520; Jalali 2012), the problems for government formation in Portugal in 2015 (Fernandes 2016), and the success of AfD in Germany (Arzheimer 2015). While many of these parties have reintroduced discourse in terms of the agenda for national identity and welfare, in terms of addressing individuals that are more affected by the economic crisis (or the so-called "globalization losers" in more general terms), there are not many studies that have attempted to measure the impact of the Great Recession on national identity in several countries.

In summary, by focusing on Germany in comparison to Southern European countries, where the impacts of the Great Recession have been qualitatively and quantitatively different, we explore how economic crises impact national identities. In the following sections, we review the concept of national identity as our dependent variable, particularly types of identity, as this has some importance for our hypotheses; second, we examine the literature on the relationship between national identity and economy, develop our working hypotheses, explain our variable operationalization, and, finally, present our analysis and tentative conclusions.

\section{National Identities and the Economy}

\subsection{Identity Typologies}

A traditional distinction has been established between ethnic and civic understandings of a nation (Brubaker 1992; Greenfeld and Chirot 2014; Maiz 2003; Miller 2000; Shulman 2002; Smith 1991). In general terms, common ancestors, common history, common language, or common religion would belong to an ethnic identity, and civic right and duties, respecting the law, and paying taxes would belong to a civic identity. Another way to look at and classify types of identities is to distinguish between ascribed and achieved identities (Jones and Smith 2001; Wright 2011). While ascribed identities are assigned upon birth (citizen parents, country of birth, etc.), achieved identities can be produced with time (mastering the language of a country, respecting national laws, feeling national, sharing cultural traditions, etc., see Guglielmi and Vezzoni 2016). We can mention a third typology by Eisenstadt and Giesen (1995) organized around symbolic codes, i.e., primordial (as 
"natural", or based in biological conditions pertaining to the gender and ethnic group), cultural, and civic codes.

In this research, we raise a national identity classification that combines the traditional distinction between a nation's ethnic and civic definitions with Wright's classification (2011) between ascribed and achieved identities. The ultimate result is, in part, close to the typology of Eisenstadt and Giesen (1995) in terms of focusing on three possible combinations. These combinations are organized in a continuum from the most closed or hermetic to the most open. First, we place the ethnic/ascribed category, which is a type of identity assigned by birth and is relevant in determining membership within the national group. The category considers factors such as place of birth, ethnicity, race, or kinship, which cannot be easily transformed on a purely voluntaristic base. Second, we place the cultural/achieved category, which includes elements such as speaking the national language, sharing religion, and respecting values and customs. These are cultural markers that can be acquired over time and allow an individual to voluntarily adhere to a certain group. Finally, the civic/achieved category is located at the most open end of the continuum. This type of identity is represented by the mere will to want to be part of a political community and share certain values and behaviors such as respect for the law, human rights, democratic values, and respect for the constitution.

The connection between these classifications and the economy is not obvious. We could conceive the economy to be relevant for the classification at two levels. First, the economic system can be thought of, at the contextual level, as a culture for the citizens born in a specific country, therefore leaning toward the ascribed dimension or the cultural one in terms of Eisenstadt and Giesen (1995). Similar to other ascribed characteristics, once a person is born in a country with a particular economic system, it is not likely that they could change that. Second, the economic condition of any citizen or group would belong to the civic/achieved identity dimension. This is because, at least in theory, that identity is composed of things that one can act upon. At this level, both the theory of realistic interest and social identity theory could be relevant. Both theories indicate the importance of status gains and losses regarding group membership (Shayo 2009). Thus, from the point of view of the theory of realistic interest, we may consider obvious gains or losses from group membership in terms of those related to the national economic status. From social identity theory, we may argue that the economic position of a group would be one of the important markers of the group's status that would be taken into account when considering membership.

In summary, from the classifications and theories above, it is obvious that there is a voluntaristic component in cultural/achieved and civic/achieved types of identities in which economic considerations may play a role. Thus, citizens have some room to decide upon their identities in terms of considering if group membership will bring about economic gains or at least an improvement in status given the economic status of the group and even the national group. In other words, in the context of the Great Recession, we may expect that cultural/achieved and civic/achieved identities transform more easily in response to changing economic conditions than ethnic/ascribed ones, and probably even in the short term.

To understand what the previous paragraphs would mean in relation to our case studies, we explore the concepts of citizens in terms of the most important characteristics to being German, Spanish, Italian, Greek, and Portuguese. This question has not been asked frequently in Eurobarometer (EB) studies for national identities, and thus we are limited to EB 73.3 (2010) within the period of our analysis. Although EB 57.2 included a similar question, the wording, the response categories, and codification were different. Different codifications were used in an attempt to carry out unfolding analysis for comparative purposes. The statistical quality of the analysis nonetheless was very low, and the results are not reported here. The main problem is that all the items offer frequencies over $95 \%$ and thus do not have discriminatory power. Additionally, Portugal is a missing case for the question in EB 57.2. We also found the absence of international databases that include 
all the cases of analysis in the period under consideration. As Figure 2 shows, the items included in EB 73.3 can be classified despite some difficulties according to the identity continuum considered here.

\begin{tabular}{|c|c|c|}
\hline Etnic/ascribed & Cultural/achieved & Civic/achieved \\
\hline$\checkmark \quad$ Place of birth & $\checkmark$ Country language & $\checkmark \quad$ Citizens rights \\
\hline \multirow[t]{5}{*}{$\checkmark \quad$ Parentage } & $\checkmark \quad$ Oficial language & $\checkmark$ Participation \\
\hline & $\checkmark \quad$ Cultural traditions & $\checkmark \quad$ Feel nationality \\
\hline & $\checkmark \quad$ Be Christian & \\
\hline & $\checkmark \quad$ Feel nationality & \\
\hline & $\checkmark \quad$ Been brought up & \\
\hline
\end{tabular}

Figure 2. Identity classification by relying on citizen understanding of the most important characteristics to be German/Spanish/Italian/Greek/Portuguese Authors' own elaboration from Eurobarometer 73.3 .

The items in gray denote a difficulty in classification. On the one hand, felt nationality is clearly an achieved trait, but it can be thought of in both cultural and civic terms. On the other hand, being raised in the country cannot be conceived as purely voluntaristic (i.e., civic achieved characteristic) since it depends on parents or tutors who decide where a child is raised, nor is it just ascribed precisely for the same reason. Therefore, we have classified it as cultural and understand that, when a person is raised in a particular context, they will gain and share some cultural traits from the national context.

Figure 3 shows the results found via unfolding analysis. The technique of multidimensional scaling, known as unfolding analysis (Cox and Cox 2001), allows one to draw a joint graphical representation of objects (countries) and stimuli (response categories) such that those that are more similar among themselves will be closer within the space than those that are more dissimilar. Furthermore, the way in which objects or stimuli cluster within the space will allow one to find the latent dimensions according to the object arrangement without imposing a priori criteria. This technique produces a joint graphical representation of the five countries (objects) and the response categories (stimuli) for which shorter distances to a stimulus represent a greater preference for it. At the same time, shorter distances between countries denote greater similarities in their preferences for different stimuli as well as greater similarities among themselves as compared to more distant countries.

As a first observation in Figure 3, we may point out that our countries are further apart on the vertical axis than the horizontal one. On the vertical axis, Germany, on the upper part, is clearly distinguished from Southern European countries, which are closer together on the bottom part. On the horizontal axis, all our case studies are very close to each other. 


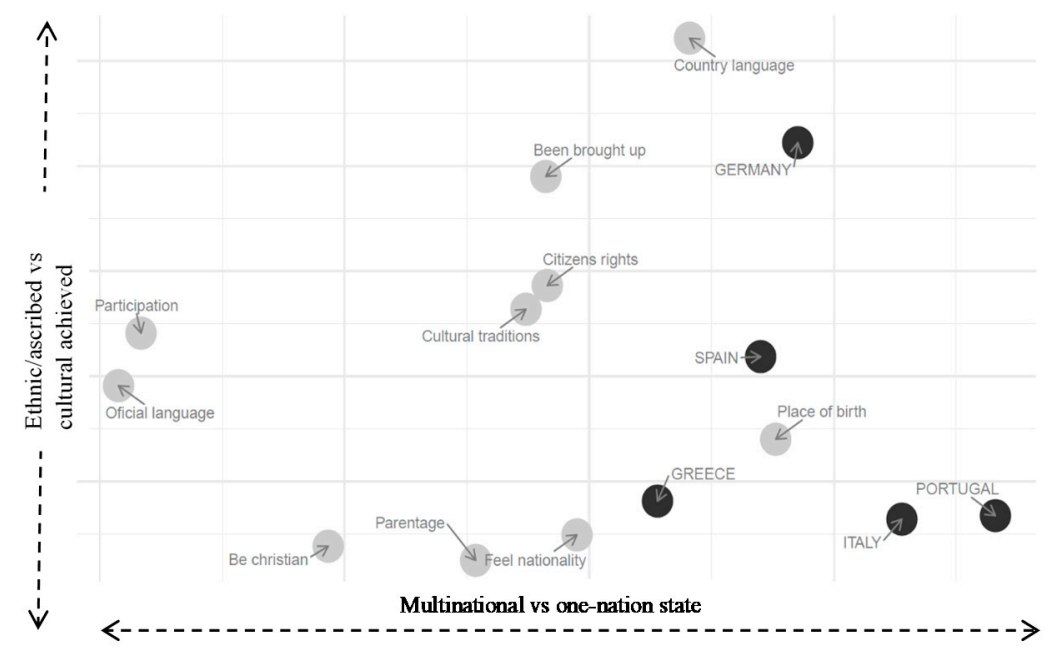

Figure 3. The meaning of national identity in Germany, Spain, Italy, Greece, and Portugal in 2010. Authors' own elaboration from Eurobarometer 73.3 via unfolding analysis.

If we examine the vertical axis, the higher importance of two traits distinguishes Germany from the Southern European countries: national language mastery and being raised in the country, both of which were included as cultural/achieved identity items. Meanwhile, Southern European citizens are closer to some of the items included as ethnic/ascribed items as shown in Figure 2, particularly parentage (having parents from the same country) and place of birth. In fact, we can think of this vertical axis as being defined between two opposites of cultural/achieved in the upper part and ethnic/ascribed in the bottom part, with other cultural and civic/achieved items moving between these two extremes.

The latent dimension organizing the horizontal axis is less clear; however, it seems to be defined by the multinational character for the country in which the citizen lives. Thus, respect for cultural traditions and official language, this item is asked only in countries with more than one co-official language, which is an indication of the multinational character of the country, remain on the left side of the axis in comparison to country language, this is the equivalent item for countries with only one official language, on the right side (together with place of birth). This dimension does not distinguish between the countries considered here in any meaningful way.

Although we do not have a temporal comparison for this analysis, we can still contribute some interesting findings regarding the importance of economy for national identities. Thus, since Germany is the country more distant to the ethnic/ascribed dimension of identity, we may also propose that changes in national identity would be larger in this country as compared to Southern European countries, and that economic variables would be more important in explaining those changes as well. Southern European countries would have experienced less change in terms of their national identity while economic variables should be less relevant in the explanation of such changes.

\subsection{Economy, Economic Crisis, and the Impacts on National Identity}

Regarding the positive connection between economy and national identity, several authors have pointed out that the self-portrayal of modern states (mainly democracies) as agents of equitable development has been the most important way in which they have fostered national identities via ideological legitimation "so that the image of the nation is reconstructed as a social justice community" (Brown 1998, p. 2; see also Crane 1998; Hettne 1993). See Shulman (2003) for a contrary position. This same idea, labeled as cohesion theory by Solt (2011), is present in the writings of Deutsch (1964) when he argues that by creating good living conditions, governments create attachment with the state. He furthermore asserts that not only maintaining well-being is necessary but also assuring the wide distribution of benefits throughout the population (Deutsch 1964, p. 143). In this 
same line, McEwen (2006, p. 51) claims that the transformation of nation states into welfare states has been most significant across advanced capitalist democracies, a change by which states have secured the consent of national minorities and accommodate their territorial identities within the framework of the nation state. Although the relation between a sense of common solidarity and welfare grown might be reciprocal, Keating (2001, p. 40) points out that it is nevertheless true that welfare states foster national identity and unity.

If good economic performance, redistribution, and the growth of welfare strengthen the state as a political community of solidarity, what are the effects of the Great Recession and the retrenchment of the welfare? There is no definitive answer for such a question in the literature. There are those who think that inequalities among individuals and groups within state boundaries lead to detachment from the national identity. Focusing on citizen feelings, Deutsch (1964, p. 146) defends that social conflicts and disintegrative tendencies emerge when the (re)distribution of wealth is too skewed. From a psychological point of view, Brown (1998, pp. 10-11) points out that the existence of inequalities can be interpreted as the absence or incompleteness of nationhood, and thus individuals who do not feel protected or secure within the imagined community of the nation state might "begin to look, and imagine, elsewhere". Usually, in the context of crisis, this means the redefinition of the understandings of insiders and outsiders, favoring more restrictive interpretations of membership, either based on the strict interpretation of citizenship or territory (state frontiers) or on ethnicity (excluding immigrants or marginalized groups that may be members of the state but not socially accepted as full members of the nation) (Brubaker 2011, pp. 94-95). In other words, inequality creates insecurity and leads individuals to closure and to be less tolerant toward minority groups within the state (Andersen and Fetner 2008, pp. 10-11), thus rejecting the idea of the social justice community. In a complementary manner, McEwen (2006) argues that a consequence of current welfare state retrenchment is the move from a state-wide identity to region-wide national identities, such as in Quebec and Scotland (see also Béland et al. 2005).

These ideas are difficult to test with empirical data since the quantitative measures of national attachment fall short in measuring the reasons for feeling belonging, but also because, as Brubaker (2011, pp. 94-95) mentions, an economic crisis does not directly translate into nationalism, i.e., political responses to economic distress situations depend on how those economic problems are framed and interpreted. Crises, in other words, are not self-interpreted. This vision is supported by authors within the "new nation theory" (Solt 2011, p. 823) where strong differences in economic well-being will encourage popular mobilization by "political entrepreneurs" attempting to develop "new" national identities among the disadvantaged members of the society. In the examples posed by McEwen (2006), the intervention of peripheral nationalist elites to create a narrative that changes attachment from the state-wide to the region-wide level is clear. Furthermore, it is one thing how elites react and frame a crisis and responses in nationalist terms and quite another in terms of how citizens react to those messages. Both levels of analysis are usually mixed and confused in the evidence that can be found on this topic in a two-fold sense regarding the operationalization of the dependent variable (if what is measured are policies or discourse by elites vs. citizen feelings of attachment) and the level at which the effects are measured (either the state itself, using aggregated data and comparing countries, or the individual; some more recent articles use both in multilevel analyses).

Brubaker (2011), for example, focused on an aggregated level of analysis, but it is not clear if he is referring to the different illustrations of government reactions or citizen attitudes. As mentioned before, he states that economic crises do not always translate into nationalism (or the same kind of nationalist responses). Solt (2011) found, contrary to the cohesion theory previously mentioned, that across countries and over time, where economic inequality is greater, nationalist sentiments are substantially more widespread. He interprets this finding as supporting the diversionary theory of nationalism according to which state elites that are unable or unwilling to redistribute wealth would potentiate nationalist messages to anesthetize people and quell social unrest; however, his data pertain 
to citizen attitudes and not to the behaviors of state elites. Shayo (2009), whose empirical finding coincides with Solt (2011) to some extent, offers psychological explanations for the fact that poor or lower-class citizens are more nationalistic than rich classes of citizens (Shulman 2003, p. 42). Other studies have explicitly focused on the consequences of the Great Recession (Ruiz Jiménez et al. 2018) and offer mixed evidence that seems to illustrate the fact the quantitative indicators used to measure national attachment might be limited. GDP erosion negatively affects the feeling of attachment to the nation, and crises also seem to exacerbate the in-group/out-group dynamic, thus promoting a protective nationalist identity as an exclusion mechanism (or welfare chauvinism; see Schumacher and Kersbergen 2016).

In summary, there is no consensus regarding theoretical or empirical evidence for the importance of economic performance for the development of attachment to a state-wide national community or the impact of crises and inequality on aloofness. This research approximates this question by focusing on a particular set of countries where a crisis has had a differential impact. Specifically, we focus on the question of national identity in Germany as compared to Spain, Italy, Greece, and Portugal and take into account the different impacts of the crisis between countries.

\section{Research Questions, Research Design, and Methods}

Our general research question focuses on the changes that have affected the national identities in the five countries considered here during the Great Recession, considering the different impacts of the economic crisis on each of them.

\subsection{Hypothesis}

Our first expectation is that the changes in the aggregate level of national identity for each country might be modest. Despite that, we expect that national identities have experienced greater erosion in countries where economic impacts have been greater. In other words, we expect greater national identity erosion in the selected Southern European countries than in Germany (H1).

This hypothesis was derived from the findings in political psychology that highlight the stability of political and social attitudes through the lifespans of individuals. Although party identification is perhaps the most stable political attitude (Green et al. 2002; Stoker and Jennings 2008), others such as national and ethnic identities are noted to persist over time once they have been acquired (Alba 1990; Alba and Nee 2003).

Although most of the theories explaining attitude stability focus on the individual level, cohort analysis (Danigelis et al. 2007) and natural experiments have provided aggregate evidence in the same sense. Interestingly for our analysis, prior acquired sociopolitical attitudes seem to resist the emergence of economic interest in adulthood (Citrin and Green 1990; Sears and Funk 1991). In summary, "the importance of early learning of partisanship, prejudice, and racial and ethnic identity now seems evident" (Sears and Brown 2013, p. 85).

Our second expectation is that the Great Recession has affected individual identities in different ways depending on the context $(\mathrm{H} 2)$.

We may expect that in countries where national identities are mainly based on ethnic/ascribed items, citizen identities would have suffered smaller changes during the Great Recession, while for countries where national identities are mainly based on achieved items (cultural or civic), we expect that citizens' identities have experienced larger movements. In other words, we expect a greater change in Germany than in the selected Southern European countries. This hypothesis also finds support in political psychology, since racial and ethnic identities have even been proven to emerge in childhood (Katz and Kofkin 1997) and to be an important step in the development of self-conceptualization during adolescence (Chao and Otsuki-Clutter 2011; Phinney 1990; Quintana 2007). Once these attitudes are acquired, they then stabilize and persist over the lifespans of individuals (Alba 1990; Alba and Nee 2003). In summary, if ethnic/ascribed elements have a strong weight within the national identity of citizens, they will not change easily, even within the 
context of the Great Recession. The findings of Citrin and Green (1990) and Sears and Funk (1991) would also support this.

A third expectation, following Shayo (2009), is that factors related to the economy will increase in their importance for national identities where and when the economy performs well (i.e., when it adds prestige to the group) and decrease in importance where and when the economy does not add prestige to the group (i.e., in the context of economic recessions). We expect that the importance of economic factors will decrease more in the selected Southern European countries than in Germany (H3). This hypothesis can also be read in combination with $\mathrm{H} 2$, where given the proposal that ethnic/ascribed identities are more resistant to change, it is in those countries where the consideration of economic factors should be more volatile depending on the national economic context, in such a way that, when economic factors do not add prestige to the national group, they would be more easily forgotten and substituted with other non-economic anchors for national identity. On the other extreme, in countries where identities are mainly cultural or civic/achieved, it is more likely that economic factors would retain their relevance in shaping attachments to the nation in positive (when the economy goes well) and negative terms (when the economic does not go well). All in all, $\mathrm{H} 2$ and $\mathrm{H} 3$ would reinforce each other regarding our expectations for the differences between Germany and the selected Southern European countries.

\subsection{Data and Operationalization}

Our ideal research design is limited by the scarcity of comparative data for our five countries. Italy, Portugal, and Greece are missing cases in most of the last releases of the international databases that fit our investigation plans. This is the case with the International Social Survey Program (ISSP). The 2013 release on "national identity" does not include Italy and Greece. See http:/ / www.gesis.org/issp/modules/issp-modules-bytopic/national-identity/2013/. (Accessed on 13 April 2021) which runs regular surveys on national identity specifically and the Word Values Survey (WVS). Greece and Portugal are missing cases for wave 5 (2005-2009). Italy, Greece, and Portugal are also missing cases in wave 6 (2010-14). See http:/ / www.worldvaluessurvey.org/WVSDocumentationWV6.jsp. Accessed on 13 April 2021. On the other hand, while these countries were included within the European Values Study (EVS) in its 2008 release, Greece is absent in the post-Great Recession wave in 2017. We can also find the countries in the European Social Survey (ESS), but this database does not include questions measuring territorial attachment or the meaning of identity. As a result, we referred to Eurobarometer (EB) data. Although reduced in the range of questions available along our temporal axis, it does include questions regarding territorial attachment and meanings of identity, as well as economic indicators that will allow us to test the impact of the economic crisis. It is important to highlight the difficulty of comparing economic factors with other ethnic, civic, attributed, or achieved traits within the same survey.

\subsection{Dependent Variable: Citizen National Identity}

The idea of "closeness" was chosen as a measure of citizen national identity. This variable pertains to the question asking how close the interviewee feels to different geographic units, among which the country is represented as a nation state in our analysis. Despite being unidimensional, this type of Bogardus scale of social distance allows measurement of the strength of attachment to the nation and does not impose any type of assumption on the respondent regarding their identity (Ruiz Jiménez 2007). Closeness is also well suited to our dependent variable because it can reflect the two-fold dimension of social identity, i.e., place identity and place attachment (Hadler et al. 2012). Furthermore, it has been extensively used by researchers of territorial identity (for a review, see Irsenia et al. 2012). 


\subsection{Independent Variables: Economic Indicators}

We consider economic variables at both the country and individual levels. At the country level, we consider GDP growth (annual \%), GDP_ppp (gross domestic product converted to international dollars using purchasing power parity rates), Gini index, unemployment (share of the labor force that is without work but available for and seeking employment), and social benefits (other than social transfers in kind) paid by the general government (measured as percentage of GDP) as variables (see Appendix A for further information). These economic data were provided by Eurostat, Word Bank national account data, and the Organization for Economic Cooperation and Development (OECD).

At the individual level, we have selected variables measuring the personal economic situations of respondents, their evaluations of national and European contexts, and expectations about the future. Finally, we have added control variables such as ideology, age, education, sex, type of community, social class, and life satisfaction. We have chosen variables that will be available in different studies before and during/after the crisis and for the different operationalizations of our dependent variable such that the results of our different models can be compared. More detailed information is given in the corresponding sections.

\section{The Great Recession and National Identity: Contextual and Individual Economic Conditions}

\subsection{Objective Impact of the Great Recession}

The previous sections have explained the different impacts of the Great Recession in our five cases. In general, Germany has fared better through the period, while Greece has suffered the most. In this section, we focus on the possible effect of the economic crisis on national identities at an aggregated (i.e., country) level.

When looking at how national attachment has changed during this period, the differences between Germany and the selected Southern European countries are immediately apparent. As seen in Figure 4, only German citizens have a percentage of feeling very close to the nation that increased (by 10\%) between 2006 and 2012. In Spain, Italy, Greece, and Portugal, the percentage of citizens who felt very attached to the nation decreased between around 2\% (Portugal and Italy) and 5\% (Greece) in the same period (Figure 4), supporting H1 at first glance. The percentages in this figure for 2006 and 2012 are slightly different to those reported in Appendix A. In Figure 4, we use the specific EB that is later used in the regression. In the Appendix A, we take the data from the GESIS EB aggregated time series. Thus, for example, the data given for 2006 are based in EB 3/2006, while for our regression, we use EB 10/2006 (EB 65.2). Table 1 shows that not only has national identity improved in Germany but also the distances between different levels of attachment between different groups of people, as measured by the standard deviation in Table 1, have decreased, where more people feel very close to the nation. On the other extreme, Greece has experienced the highest loss in the percentage of citizens very attached to the nation, a result that was more consistent among Greek citizens in 2012 than 2006 (see the standard deviation in Table 1). In Spain, Italy, and Portugal, the national identity situations have also worsened and the distances between the levels of attachment among different groups of people have increased (see standard deviation in Table 1). This points toward certain levels of polarization in national identities in 2012 as compared to 2006 in Spain, Italy, and Portugal. 

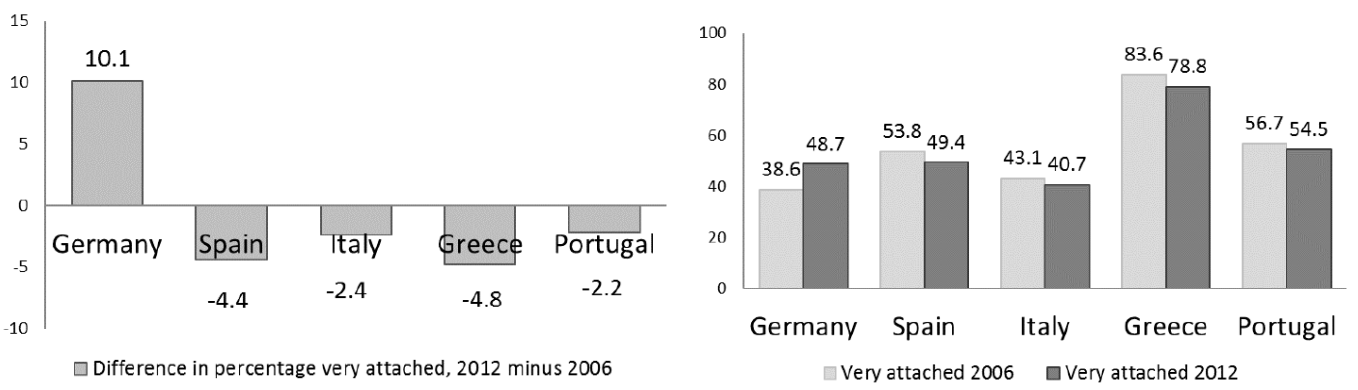

Figure 4. Percentages of citizens who feel very attached to the nation before and after the Great Recession. Authors' own elaboration from EB 65.2 (2006) and EB 77.3 (2012).

Table 1. Mean attachment among Germany, Spain, Italy, Greece, and Portugal before and after the Great Recession. Authors' own elaboration from EB 65.2 (2006) and EB 77.3 (2012).

\begin{tabular}{ccccc}
\hline & \multicolumn{2}{c}{2006} & & \multicolumn{2}{c}{$\mathbf{2 0 1 2}$} \\
\hline & Mean & Sd & Mean & Sd \\
\hline Germany & 3.23 & 0.731 & 3.41 & 0.647 \\
Spain & 3.42 & 0.721 & 3.31 & 0.811 \\
Italy & 3.32 & 0.698 & 3.24 & 0.775 \\
Greece & 3.82 & 0.435 & 3.77 & 0.0456 \\
Portugal & 3.72 & 0.492 & 3.44 & 0.627 \\
\hline
\end{tabular}

If we consider the standard errors of the sample, only the changes for Germany are statistically significant. The sample sets consist of around 1000 individuals on average for the different countries, where, considering a confidence interval of $95 \%(p=q=50 \%)$, the standard error would be +3.1 . Only the 10\% change in Germany between 2006 and 2012 is larger than the error. The changes in Spain and Italy would be on the limit for a confidence interval of $90 \%$. Thus, we cannot argue that there have been significant changes in the percentages of strong national identity holders in the selected Southern European countries, while the change in Germany might also be modest when discounting the standard error. In summary, these findings are consistent with $\mathrm{H} 1$ regarding both the modest amount of change and the directions of such changes.

To test the correlation, we performed analysis at the country level between our economic indicators and the percentages of citizens very attached and quite attached to their country from 2000 to 2012 (see Table 2). At first glance, the direct impacts of economic trends on identity seem to be quite limited. Only in the case of Germany is national attachment linked with economic trends in a two-fold sense, where country attachment is positively correlated with an increase in GDP_ppp and negatively related to inequality as measured by the Gini index. Therefore, these findings seem to also support $\mathrm{H} 1$ in general regarding the impact of the Great Recession on national identity, and H2, in particular, regarding a different impact in Germany as compared to the selected Southern European countries. In fact, only in Germany is the longitudinal correlation in aggregate terms statistically significant. A logical finding since we have established before that only in Germany is the change in national identity statistically significant (i.e., only in Germany is there enough variability in the dependent variable). Correlations were also statistically significant only for Germany when using "fairly attached" instead of "very attached". 
Table 2. Correlations between economic trends and national identity (percentage of citizens very attached to country) in Germany, Spain, Italy, Greece, and Portugal in 2000-2012. Authors' own elaboration from several sources (see Appendix A). $p$ values: ${ }^{* *} \leq 0.01$.

\begin{tabular}{cccccc}
\hline & Germany & Spain & Italy & Greece & Portugal \\
\hline GDP & $\mathrm{ns}$ & $\mathrm{ns}$ & $\mathrm{ns}$ & $\mathrm{ns}$ & $\mathrm{ns}$ \\
GDP_PPP & $0.894^{* *}$ & $\mathrm{~ns}$ & $\mathrm{~ns}$ & $\mathrm{~ns}$ & $\mathrm{~ns}$ \\
GINI & $-0.997^{* *}$ & $\mathrm{~ns}$ & $\mathrm{~ns}$ & $\mathrm{~ns}$ & $\mathrm{~ns}$ \\
Percentage of unemployment & $\mathrm{ns}$ & $\mathrm{ns}$ & $\mathrm{ns}$ & $\mathrm{ns}$ & $\mathrm{ns}$ \\
Social security transfers & $\mathrm{ns}$ & $\mathrm{ns}$ & $\mathrm{ns}$ & $\mathrm{ns}$ & $\mathrm{ns}$ \\
\hline
\end{tabular}

\subsection{Individual Subjective Perceptions of the Economy}

Previously, we have focused on aggregate measures at the country level, and here we analyze individual Eurobarometer data. We have selected two studies pre- and post-crisis. EB 65.2 was carried out in 2006 and contains mostly the same independent variables to be used in the analysis of EB 77.3 which was carried out in 2012.

The independent variables in our models include the evaluation by the respondent of the current situations for the national economy, European economy, personal job situation, the financial situation of their household, the employment situation of the country, and the situation of national welfare (available only for 2006 studies), as well as the expectations of the respondent for the next 12 months regarding life in general, the economic situation, the financial situation of their household, the employment situation in the country, and their expectations for their personal job situation. As regular socio-demographic controls, we have included ideology, age, education, sex, occupation, level in society, and frequency of political discussion.

Due to the distributions and statistical characteristics of our dependent variables in the different EBs, we finally opted for logistic binomial regression for analysis. Thus, our dependent variable has been recoded as a dummy variable with a value of 1 representing those very attached to their country (50\% on average in the different studies and countries), while a value of 0 denotes those who feel fairly attached, not very attached, or not at all attached. Although the distribution of the variable is different across countries, we looked for a common operationalization that could suit all countries.

A descriptive analysis of our independent variables shows that evaluations and expectations regarding economic indicators worsened between 2006 and 2012 in general terms (Table 3). Furthermore, it is interesting to note the changes among countries in this five-year period. In 2006, Spain was the country with consistently better evaluations and expectations, joined by Italy and Germany depending on the indicator (Figure 5). Greece and Portugal, on the other hand, tended to share worse evaluations for economic indicators and to be less optimistic about the future. In 2012, Germany (Figure 6) was the country with the best evaluation for all of the economic indicators included in our analysis. All selected Southern European countries shared consistently worse evaluations for any of the items. Regarding expectations for the next twelve months, Spain and Italy were more optimistic than Greece and Portugal. These two countries continued to have the worst evaluation and expectations means also in 2012. It is interesting to note that Greece and Portugal, the two countries with the worst economic evaluation and expectations, are those with the higher percentages of citizens feeling very attached to the nation. These are idiosyncratic characteristics of both countries, and therefore we focus on increasing or diminishing trends here, not differences among countries in the net percentages of attached and detached citizens. On the other extreme, Spain and Germany are the countries with the weakest national attachments in part due to the reaction against the previous monopolization of patriotism by Fracoism and Nazism, respectively (Table 1), even if that percentage decreased after the Great Recession. 
Table 3. Changes in the subjective perceptions of the economy by respondents in Germany, Spain, Italy, Greece, and Portugal from 2006 to 2012. Current situation: 1-very bad, 2-rather bad, 3-rather good, 4-very good. Expectations: 1-worse, 2-same, 3-better. Source is authors' own elaboration from Eurobarometer 65.2 and 77.3.

\begin{tabular}{|c|c|c|c|c|}
\hline & \multicolumn{2}{|r|}{2006} & \multicolumn{2}{|r|}{2012} \\
\hline & Mean & Standard Deviation & Mean & Standard Deviation \\
\hline Current situation: national economy & 2.07 & 0.760 & 1.79 & 0.871 \\
\hline Current situation: European economy & 2.55 & 0.700 & 1.86 & 0.672 \\
\hline Current situation: personal job situation & - & - & 2.37 & 0.910 \\
\hline Current situation: financial situation of household & 2.50 & 0.722 & 2.36 & 0.791 \\
\hline Current situation: employment in country & 1.72 & 0.717 & 1.65 & 0.808 \\
\hline Current situation: national welfare situation & 2.22 & 0.781 & - & - \\
\hline Expectations next 12 months: life in general & 2.08 & 0.688 & 1.87 & 0.654 \\
\hline Expectation next 12 months: economic situation & 1.72 & 0.752 & 1.62 & 0.704 \\
\hline $\begin{array}{l}\text { Expectations next } 12 \text { months: financial situation of } \\
\text { household }\end{array}$ & 1.92 & 0.672 & 1.78 & 0.640 \\
\hline $\begin{array}{c}\text { Expectations next } 12 \text { months: employment situation of } \\
\text { country }\end{array}$ & 1.67 & 0.745 & 1.56 & 0.697 \\
\hline Expectations next 12 months: personal job situation & 2.05 & 0.562 & 1.88 & 0.594 \\
\hline
\end{tabular}
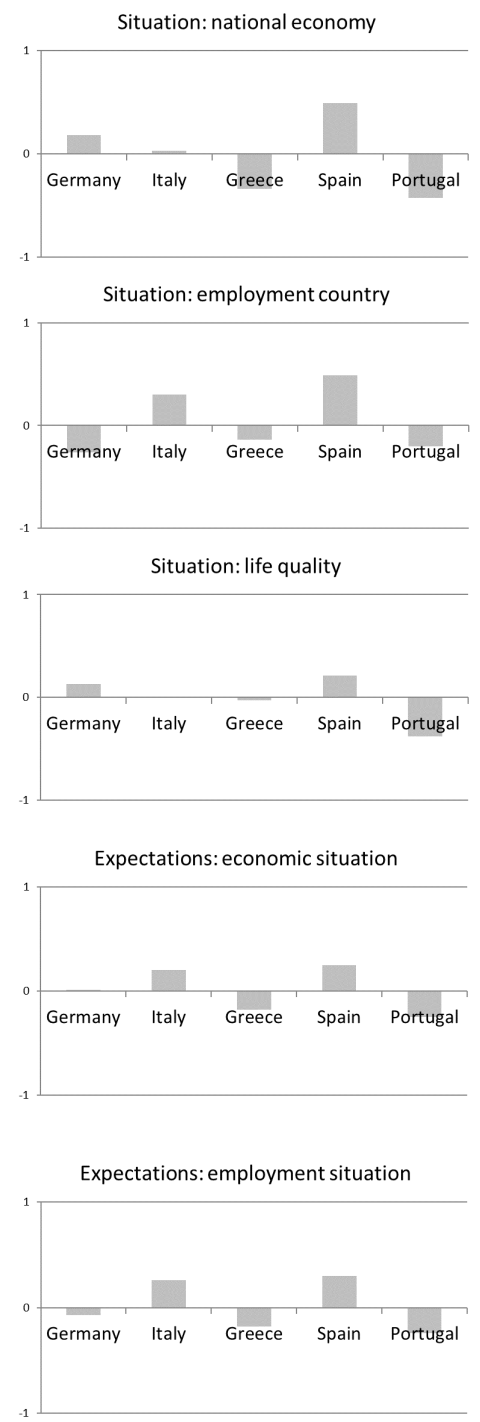
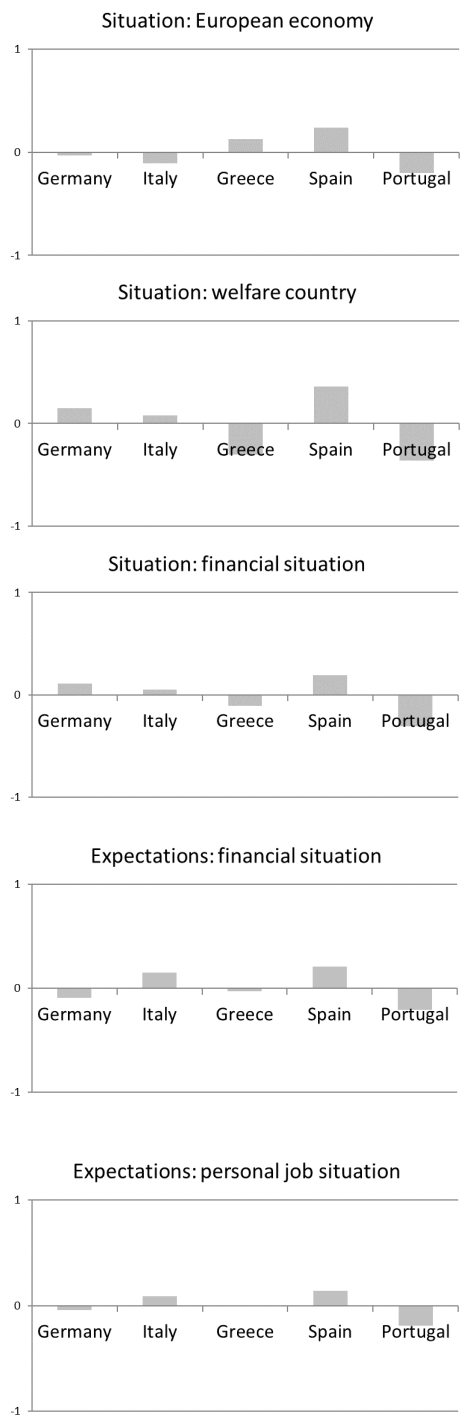

Figure 5. Differences among citizen evaluations and expectations regarding economic indicators in Germany, Spain, Italy, Greece, and Portugal in 2006 (mean evaluation in each country minus average evaluation for our five cases). Source is authors' own elaboration from Eurobarometer 65.2. 

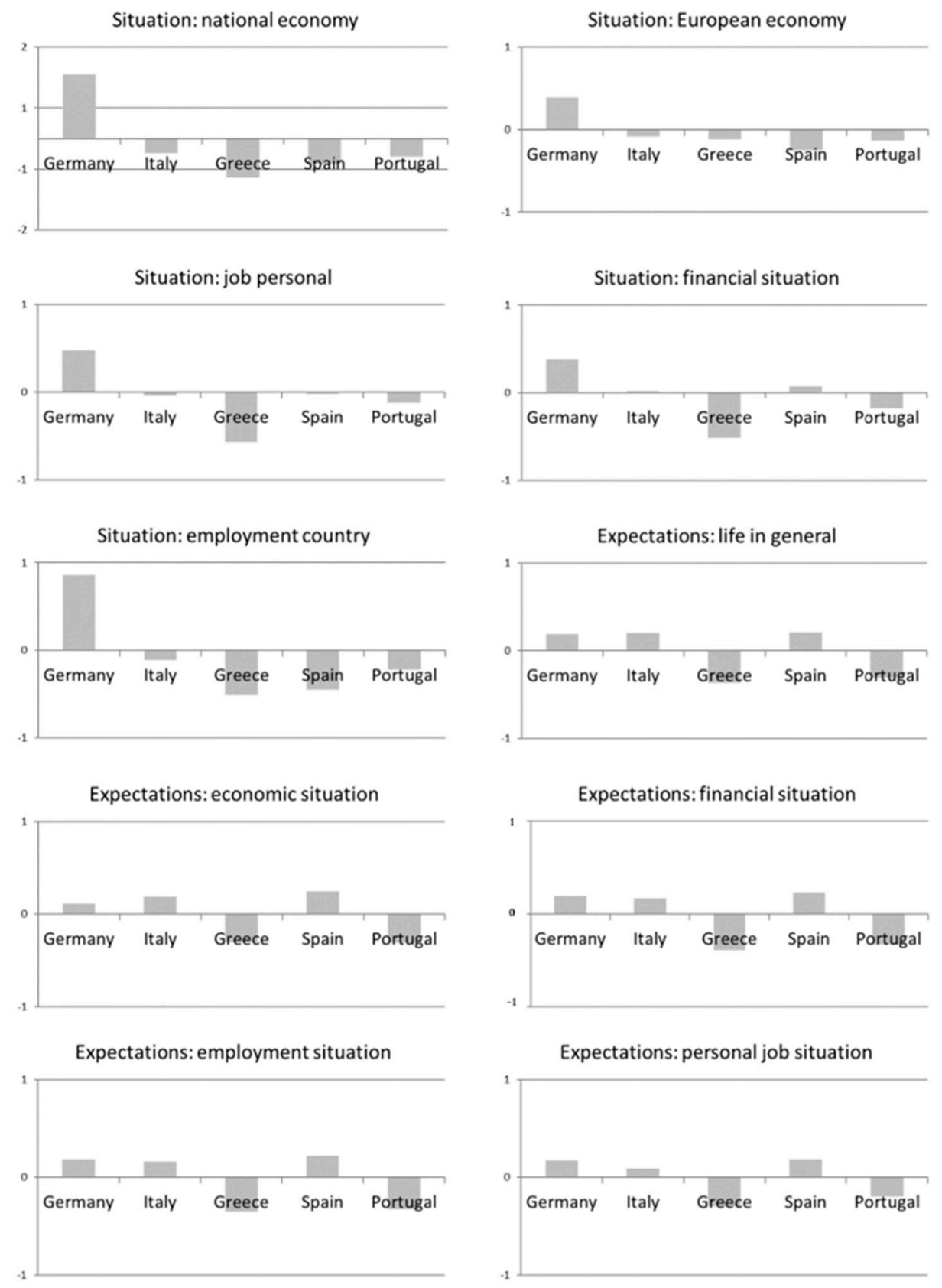

Figure 6. Differences among citizen evaluations and expectations regarding economic indicators in Germany, Spain, Italy, Greece, and Portugal in 2012 (mean evaluation in each country minus average evaluation for our five cases). Source is authors' own elaboration from Eurobarometer 77.3.

A preliminary bivariate analysis confirmed that these economic variables were correlated with the national identity indicators (Table 4). The correlations were low and negative both in 2006 and 2012. As evaluation and expectations regarding economic indicators worsened, individual national attachment increased. These preliminary findings tend to agree with the arguments by Brubaker (2011) and Andersen and Fetner (2008) regarding the effects of relative economic deprivation on national identity. Those correlations showed no systematic changes between 2006 and 2012, although some increased and decreased from one year to the other. It is interesting to note how several factors related to the evaluation of the European economy, as well as the expectations regarding the economic and employment situation of the country, cease to be significant in 2012 for the feeling of attachment to the national group, suggesting that economic factors might play a more relevant role in positive contexts than negative contexts. This finding would be in favor of 
$\mathrm{H} 3$, suggesting that the economic variables have become less salient for national identities after the Great Recession.

Table 4. Aggregate non-parametric correlations (tau-b) between economic perceptions and attachment to the country. Current situation: 1-very bad, 2-rather bad, 3-rather good, 4-very good. Expectations: 1—worse, 2-same, 3-better. Source is authors' own elaboration based on Eurobarometer 65.2 and 77.3. $p$ values: ${ }^{*} \leq 0.05,{ }^{* *} \leq 0.01$.

\begin{tabular}{|c|c|c|}
\hline & 2006 & 2012 \\
\hline Current situation: national economy & $-0.099^{* *}$ & $-0.089 * *$ \\
\hline Current situation: European economy & $0.033 *$ & ns \\
\hline Current situation: personal job situation & - & ns \\
\hline Current situation: financial situation of household & ns & $-0.029 *$ \\
\hline Current situation: employment in country & $-0.027 *$ & $-0.077^{* *}$ \\
\hline Current situation: national welfare situation & $-0.042 * *$ & - \\
\hline Expectations next 12 months: life in general & $-0.048^{* *}$ & $-0.073^{* *}$ \\
\hline Expectation next 12 months: economic situation & $-0.038^{* *}$ & ns \\
\hline Expectations next 12 months: financial situation of household & $-0.027 *$ & $-0.029 *$ \\
\hline Expectations next 12 months: employment situation of country & $-0.054^{* *}$ & ns \\
\hline Expectations next 12 months: personal job situation & $-0.029 *$ & $-0.039 * *$ \\
\hline
\end{tabular}

Tables 5 and 6 present two series of logistic regression analysis for 2006 and 2012 for our five cases. In general, it can be noted that these regressions are able to explain more variance in the national identities of citizens in 2006 before the Great Recession than in 2012, which is a finding that again runs in favor of H3. Thus, the $\mathrm{R}^{2}$ for a general regression including citizens from all five countries together drops from 0.25 ( $25 \%$ of explained variance on average) to 0.14 . The losses of explanatory power were larger in the selected Southern European countries, whereas in Germany (where the percentage of strongly attached citizens has increased over the period), the explanatory power of regression experienced almost no change. Thus, in Germany, the explanatory power dropped by only $1 \%$ from $13 \%$ of explained variance to $12 \%$, while for the other Southern European countries, Spain showed a change from $23 \%$ to $13 \%$; Italy from $13 \%$ to $10 \%$; Greece from $24 \%$ to $9 \%$; and Portugal from $27 \%$ to $21 \%$. In summary, our ability to understand national identities based on the economic perceptions of citizens is lower in part because of the Great Recession.

Table 5. Impact of economic factors on national attachment: Germany, Spain, Italy, Greece, and Portugal (2006). VD: 0, not very attached; 1, very attached. Source is authors' own elaboration based on EB 65.2. $p$ values: ${ }^{*} \leq 0.05,{ }^{* *} \leq 0.01,{ }^{* * *} \leq 0.001$.

\begin{tabular}{|c|c|c|c|c|c|c|}
\hline \multirow[b]{2}{*}{ Variable } & \multicolumn{6}{|c|}{$\operatorname{Exp}(b)$} \\
\hline & $\begin{array}{c}\text { All } \\
\text { Countries }\end{array}$ & Germany & Italy & Greece & Spain & Portugal \\
\hline Sit: economy country & & & & & & $0.555 *$ \\
\hline Sit: European economy & & $0.772 * *$ & & & & \\
\hline Sit: employment country & $0.780 * *$ & & $0.678^{* *}$ & $0.552 * *$ & & $1.956^{* *}$ \\
\hline Sit: environment country & $1.161^{* *}$ & & & $1.459 * *$ & & \\
\hline \multicolumn{7}{|l|}{ Sit: welfare country } \\
\hline Sit: quality of life resp. & & & & $1.713^{* *}$ & $1.727^{* *}$ & \\
\hline Sit: financial situation resp. & & & & & 0.624 * & \\
\hline Exp: life in general & & & & $0.664 *$ & $1.505 *$ & \\
\hline Exp: economic situation & $1.174^{* *}$ & & & $1.840^{* *}$ & & \\
\hline
\end{tabular}


Table 5. Cont.

\begin{tabular}{|c|c|c|c|c|c|c|}
\hline \multirow[b]{2}{*}{ Variable } & \multicolumn{6}{|c|}{$\operatorname{Exp}(b)$} \\
\hline & $\begin{array}{c}\text { All } \\
\text { Countries }\end{array}$ & Germany & Italy & Greece & Spain & Portugal \\
\hline Exp: financial situation household & & $0.780 *$ & & & & \\
\hline Exp: employment situation of country & & & & & $0.617^{* * *}$ & \\
\hline \multicolumn{7}{|l|}{ Exp: personal job situation } \\
\hline Left-right self-placement & $1.080^{* * *}$ & $1.109^{* * *}$ & & & $1.222 * * *$ & \\
\hline Age & $1.020 * * *$ & $1.012 *$ & 1.021 ** & $1.048^{* * *}$ & $1.044^{* * *}$ & $0.980 *$ \\
\hline Education & $0.995 *$ & $0.988^{* *}$ & & & & \\
\hline \multicolumn{7}{|l|}{ Sex } \\
\hline \multicolumn{7}{|l|}{ Type of community (ref. large town) } \\
\hline (1) Rural area & $1.297 * *$ & & $0.490 * *$ & $2.344^{* * *}$ & & \\
\hline (2) Small/Middle town & & & & & & $0.337^{* * *}$ \\
\hline \multicolumn{7}{|l|}{$\begin{array}{l}\text { Occupation (ref. manual workers and } \\
\text { farmers) }\end{array}$} \\
\hline \multicolumn{7}{|l|}{$\begin{array}{l}\text { (1) Students or responsible for } \\
\text { ordinary shopping, etc. }\end{array}$} \\
\hline \multicolumn{7}{|l|}{ (2) Unemployed } \\
\hline (3) Retired & & & & & $0.399 *$ & \\
\hline \multicolumn{7}{|l|}{ (4) Professional, high management } \\
\hline \multicolumn{7}{|l|}{ (5) Middle management } \\
\hline Life satisfaction & $1.273^{* * *}$ & $1.297 * *$ & & & $1.552 * *$ & \\
\hline Frequency of political discussion & & $1.226^{* * *}$ & $1.417^{* *}$ & & $0.745 *$ & $0.458^{* * *}$ \\
\hline Democracy satisfaction & $1.365^{* * *}$ & & $1.372 * *$ & $1.381 * *$ & $1.496^{* *}$ & \\
\hline \multicolumn{7}{|l|}{ Country (ref. Portugal) } \\
\hline (1) Germany & $0.144^{* * *}$ & & & & & \\
\hline (2) Italy & $0.250^{* * *}$ & & & & & \\
\hline (3) Greece & $1.460 * *$ & & & & & \\
\hline (4) Spain & $0.309^{* * *}$ & & & & & \\
\hline Constant & $0.249^{* * *}$ & $0.052^{* * *}$ & $0.050^{* * *}$ & $\mathrm{~ns}$ & $0.004^{* * *}$ & ns \\
\hline $\mathrm{N}$ & $3228 / 5533$ & $1134 / 1526$ & $471 / 1000$ & $720 / 1000$ & $462 / 1005$ & $441 / 1002$ \\
\hline Sig. & 0.000 & 0.000 & 0.024 & 0.000 & 0.306 & 0.000 \\
\hline $\mathrm{R} 2$ & 0.249 & 0.133 & 0.126 & 0.238 & 0.226 & 0.267 \\
\hline Correctly classified & $57 / 69.6$ & $60.8 / 66.4$ & $55.2 / 65.2$ & $83.8 / 84.9$ & $54.4 / 66.7$ & $77.3 / 79.8$ \\
\hline
\end{tabular}

Table 6. Impact of economic factors on national attachment: Germany, Spain, Italy, Greece, and Portugal (2012). VD: 0, not very attached; 1 , very attached. Source is authors' own elaboration based on EB 77.3. $p$ values: ${ }^{*} \leq 0.05,{ }^{* *} \leq 0.01,{ }^{* * *} \leq 0.001$.

\section{$\operatorname{Exp}(b)$}

\section{Variable}

Sit: economy country

Sit: European economy

Sit: employment country

Sit: world economy

Sit: job personal

\section{All}

Countries

Germany

Italy

Greece

Spain

Portugal
$1.741^{* *}$

$0.457^{\text {** }}$

$0.665^{\text {** }}$

$0.975^{* * *} \quad 1.351^{* *}$


Table 6. Cont.

\begin{tabular}{|c|c|c|c|c|c|c|}
\hline \multirow[b]{2}{*}{ Variable } & \multicolumn{6}{|c|}{$\operatorname{Exp}(b)$} \\
\hline & $\begin{array}{c}\text { All } \\
\text { Countries }\end{array}$ & Germany & Italy & Greece & Spain & Portugal \\
\hline Difficulties paying bills & $0.842 * *$ & $0.728^{* *}$ & & & & $0.732^{*}$ \\
\hline \multicolumn{7}{|l|}{ Sit: financial situation resp. } \\
\hline Exp: life in general & & & & & $0.671^{*}$ & $0.671 *$ \\
\hline Exp: economic situation & & 1.278 * & & & & \\
\hline Exp: financial situation household & $1.260 * *$ & $1.389 * *$ & & & & $2.381 * * *$ \\
\hline \multicolumn{7}{|l|}{ Exp: employment situation of country } \\
\hline Exp: personal job situation & $1.309 * * *$ & $1.085^{* *}$ & & & & \\
\hline Exp: economic situation Europe & $0.872 * * *$ & & & & & \\
\hline Exp: economic situation world & $1.289 * *$ & & & & & \\
\hline Age & $1.009 * * *$ & & & $1.028^{* * *}$ & & \\
\hline \multicolumn{7}{|l|}{ Education } \\
\hline Sex & $1.180^{* *}$ & & & & & $1.511^{* *}$ \\
\hline \multicolumn{7}{|l|}{ Type of community (ref. large town) } \\
\hline \multicolumn{7}{|l|}{ Rural area } \\
\hline \multicolumn{7}{|l|}{ Small/Middle town } \\
\hline \multicolumn{7}{|l|}{$\begin{array}{l}\text { Occupation (ref. manual workers and } \\
\text { farmers) }\end{array}$} \\
\hline $\begin{array}{l}\text { Students or responsible for ordinary } \\
\text { shopping, etc. }\end{array}$ & $1.455^{* *}$ & & & & & $3.255^{* *}$ \\
\hline Unemployed & & & & & $2.450 * *$ & $1.806^{*}$ \\
\hline Retired & $1.355^{* *}$ & & & & & 2.211 \\
\hline Professional, high management & $0.783 *$ & $0.528 * *$ & & & & \\
\hline Middle management & & & & & & $2.251 * *$ \\
\hline Social class self-assessment & $0.770 * * *$ & $0.640^{* *}$ & & & & \\
\hline Social class (recode) & & & 0.754 * & & & \\
\hline Life satisfaction & & & $1.318^{*}$ & & & \\
\hline Frequency of political discussion & $1.313^{* * *}$ & $1.381 * *$ & $1.420 * *$ & & & $1.919 * * *$ \\
\hline Democracy satisfaction & $1.115^{* *}$ & & & & $1.508^{* * *}$ & \\
\hline \multicolumn{7}{|l|}{ Country (ref. Portugal) } \\
\hline Germany & $0.580^{* * *}$ & & & & & \\
\hline Italy & $0.547^{* * *}$ & & & & & \\
\hline Greece & $3.203^{* * *}$ & & & & & \\
\hline Spain & $0.621^{* * *}$ & & & & & \\
\hline Constant & $0.454^{* *}$ & $0.196^{* *}$ & ns & ns & $0.218^{*}$ & ns \\
\hline $\mathrm{N}$ & $3340 / 5555$ & $952 / 1502$ & $597 / 1036$ & $663 / 1006$ & $632 / 1006$ & $596 / 1010$ \\
\hline Sig. & 0.000 & 0.000 & 0.000 & 0.000 & 0.000 & 0.003 \\
\hline $\mathrm{R} 2$ & 0.137 & 0.124 & 0.098 & 0.086 & 0.127 & 0.210 \\
\hline Correctly classified & $54 / 63.7$ & $52.5 / 64.2$ & $58.5 / 64.5$ & $77.5 / 77.8$ & $51.4 / 61.4$ & $562 / 68.5$ \\
\hline
\end{tabular}

As a second observation, the importance of economic evaluations and expectations for the national identities of citizens is variable among different countries, and the relative importance does not follow the same pattern in all of them either, which could be a finding 
compatible with $\mathrm{H} 2$. In general terms, different effects can stem from the same cause (or indeed from a combination of causes) (Mackie 1965). Effects can vary, particularly across countries, but even within a country, some people may become estranged from their national identity as a consequence of an economic crisis because they do not feel protected or taken care of, and others may present their identity as "national" to reinforce their entitlement to some particular social benefits from which they would exclude nonnationals (thus promoting welfare chauvinism). Nonetheless, we have tried to develop some predictions regarding how those effects may differ across countries in terms of $\mathrm{H} 2$. Neither Germany nor the selected Southern European countries among themselves were similar. This finding supports the idea that economic factors and particularly the Great Recession's impact on national identities depend strongly on how it is understood in each country. Remember that we suggested higher percentages of change and higher importance for economic variables for Germany than the rest of the countries, taking into account the relative higher importance of cultural/achieved traits of national identity in that country as compared to the selected Southern European ones (see comments of Figure 1).

In Germany, where the impact of the Great Recession has been lower, the percentage of citizens very attached to the nation increased by $10 \%$ on average between 2006 and 2012. At the same time, the relative importance of the economic variables included in our regression has also changed. Only two economic variables were relevant in 2006 for developing a strong attachment with the nation, and both were expressed in negative terms, i.e., a negative evaluation of the European economy and holding negative expectations regarding the financial situation of the household. In 2012, seven economic variables were statistically significant, and most of them were expressed in positive terms, namely, to hold positive expectations regarding the employment situation in the country, the personal employment situation, and the economic situation of the country; a positive evaluation of the current personal employment situation; not having a problem to pay bills; being of low social class and being a manual worker (as compared to professionals and high-ranking workers). This finding partially backs $\mathrm{H} 2$.

Greece experienced the worse situation among our five cases, although we are less certain about the decrease in the percentage of citizens very attached to the nation during the period of the Great Recession analyzed in this research. The relative importance of the economic variables included in our regression changed, although not in the same sense as in Germany. In this case, the relative importance of the economic variables decreased. In Greece, four economic variables were relevant in 2006 for upholding strong feelings of attachment to the nation, namely, to have negative evaluations of the employment situation in the country; to have negative expectations over life in general; to have positive expectations of the economic situation of the country; and positive evaluations of the quality of life in the country. In contrast, in 2012, only one variable remained statistically significant, namely, to uphold a negative evaluation of the employment situation in the country. Since, at the same time, Greece was closer to an ascribed understanding of identity, this finding is also consistent with $\mathrm{H} 2$ and $\mathrm{H} 3$.

These two extreme cases among our five countries seem to suggest that the economic variables are more relevant in positive economic contexts than negative ones. When the economy is perceived to be doing well (or better than neighboring economies), it serves as an anchor for developing or maintaining strong attachment to the nation, probably adding to pre-existing anchorages of national identity; however, when it is perceived to be doing poorly (or worse than neighboring economies), it loses importance and people return to different anchorages for upholding strong national identities.

Among these two extremes represented by Germany and Greece, the three remaining Southern European countries present some variability. In Spain, with the second largest loss in citizens very attached to the nation over the analyzed period, economic variables also lost importance. In Italy and Portugal, where the decreases in the percentages of citizens very attached to the nation were weaker, the relative importance of economic variables increased similarly to Germany, although more in Portugal than in Italy. 
These findings offer mixed support for $\mathrm{H} 2$ and $\mathrm{H} 3$. On the one hand, the correlations found mean that we cannot rule out the hypothesis that the Great Recession has had an impact on national identities, while, on the other hand, it is not true for all cases that the roles of economic factors are more relevant after the crisis. Instead, each country seems to follow its own path regarding the importance of economic factors for upholding strong national identities. While the relative importance has increased in countries such as Germany, it has decreased in others. As suggested by H3, although it will need further research, it seems that economic factors are more relevant when an economy is performing well. In this moment, the economy will probably reinforce pre-existing national identities. During an economic crisis, most citizens will still uphold their national identities as this tends to be a stable attitude once acquired and will therefore look or return to different anchorages, forgetting, to a certain extent, about economic variables. Consistent with Shayo (2009), citizens would look for sources of group pride or prestige in places where they can find it, therefore paying less attention to the economy when it is performing poorly (i.e., when it will decrease a group's prestige) than when it goes well (i.e., when it will add prestige). These differences are consistent with $\mathrm{H} 2$, since the extent of change and the importance of economic factors during the Great Recession were larger for Germany than for the selected Southern European countries, while at the same time, the cultural/achieved dimension of identity was also more relevant in the former and the latter (Figure 1).

\section{Discussion and Conclusions}

The purpose of this research was to analyze if, and how, the Great Recession has affected national feelings of belonging (i.e., national identity). Our conclusions are centered around three hypotheses that relate national identity to economic changes, both at the aggregate level and the individual level.

Focusing on our specific hypotheses, our data support H1. Although at first sight, and in aggregate terms, national identities have changed in all our cases, the change is significant only in Germany. In all other countries, the amounts of change are smaller than the standard errors of the samples. Note that samples are usually around 1000 units for what can be considered as an infinite population size; with $\mathrm{p}=\mathrm{q}=50$, the standard error of the sample is $\pm 3.1 \%$ within a $95 \%$ confidence interval. Taking into account these errors, the variations might also be modest in Germany. Therefore, in line with Citrin and Green (1990) and Sears and Funk (1999), our findings suggest that identities, once acquired, are stable and resistant to change, even in the context of an economic crisis. One caveat to consider is the fact that we are not measuring longitudinal individual change, but rather the aggregate percentage of citizens holding strong attachment to the nation from one moment to the other. Therefore, this figure might hide individual changes in directions that cancel each other from one survey to the other, although this is not what political psychology suggests (Sears and Brown 2013). H1 also states that the economic variables would have different impacts in Germany and the selected Southern European countries, given the different impact of the Great Recession on them. This hypothesis is clearly supported by our analysis. In the first place, Germany is the only country with a significant change in the aggregate number of strong national identity holders (Table 1); it is also the only one where the change is positive: the number of people strongly attached to the country has increased during the period of the Great Recession (Table 1, Figure 6). Although the percentages of change were not statistically significant in the Southern European countries here, in all of them, the trends point toward a lowering in the number of strong national identity holders in contrast to Germany. This suggests a correlation between the relative importance of the crisis and identity, which was only confirmed for Germany (Table 2). We have already mentioned how economic factors have gained importance for the understanding of strong attachment to the nation in Germany, where the explanatory power of our regression holds (Tables 5 and 6); however, in the Southern European countries, the economic evaluations and expectations of citizens do not help us to better understand their national identities after the Great Recession (the explanatory power of our regressions diminishes). 
Despite this overall stability in the number of people strongly attached to their countries, the Great Recession has affected individual national identities in different ways, which is a finding that is compatible with $\mathrm{H} 2$. In this sense, we have already pointed out that Germany is the only country where changes in the percentages of citizens strongly attached to the nation can be considered statistically significant. For this country, economic variables also play a more relevant role in individual national identities after the Great Recession than before (Tables 5 and 6). This is also consistent with the fact that Germany was the country in which citizens were closer to the cultural/achieved dimension of identity in Figure 1. If we consider Spain and Greece in this comparison, with percentages of change in aggregate figures of strong national identity holders lower than Germany (However, remember that our confidence interval regarding the change in these two countries will be considerably smaller (less than $90 \%$ ). Additionally, the change in Greece and Spain is negative, while in Germany, it is positive) and closer to the ascribed dimension of identity in Figure 1, we find that the number of economic variables relevant for the national identity of citizens does in fact diminish during the same period (Tables 5 and 6). These same results point toward our third hypothesis. Thus, the explanatory power of our regression models, including the economic variables, has diminished for all of the selected Southern European countries where the impacts of the economic crisis have been larger. As a country's economic performance adds to its prestige in terms of national belonging, the explanatory power of the economic factors lowered from 2006 to 2012. Meanwhile, in Germany, our regression models kept their explanatory power for individual national identity (Tables 5 and 6). Economic variables increased their importance in some countries and diminished in others in a manner consistent with $\mathrm{H} 2$ and $\mathrm{H} 3$.

Good operationalization of economic anchorages has been considered here, but our models do not include indicators of alternative identity anchorages. Thus, we cannot evaluate if the aggregate percentages of strong identity holders have remained stable in Spain and Greece despite the Great Recession, as ethno-cultural anchorages have regained importance in light of the economic evaluations and expectations of citizens; however, the fact that our regression loses explanatory power is consistent with this idea. We cannot prove that the increasing importance of economic variables in Germany goes hand in hand with the diminishing importance of ethno-cultural anchorages in this country. This limitation in our regressions is due to the absence in EB of fitted questions for the operationalization of different meanings of national identity; however, while there are better databases for measuring national identity, Greece and Portugal are missing cases in most of them. Therefore, with the limited data at hand, we find more evidence in favor of than against $\mathrm{H} 2$ and $\mathrm{H} 3$; however, more investigation would be necessary in this regard. It is also worth mentioning that our models have only included the main subjective evaluations of citizens about their country's economic situation. While a country's objective economic performance might be interesting for analysis, our five countries do not present enough second level (i.e., country) variability to allow for such analysis; however, to account for this contextual effect, we introduced countries with fixed effects in our first model. Additionally, the general perceptions and expectations of citizens regarding the economic situation are correlated with other objective economic indicators as presented in the introduction. Another reflection has to do with the fact that there might be some underlying dimensions affecting both our dependent and independent variables (national identity and subjective evaluation of the economy). While this might be possible, two observations disregard it as likely: first, the already noted correlation between the objective economic impact of the economic crisis in our set of countries and the subjective perceptions that citizens hold, and, second, the fact that negative evaluations of the economic situations might lead to different outcomes, as already noted.

To conclude, our results point to the fact that the roles and impacts of economic variables might be different depending on the relative economic performance of a country within its own context. Thus, it seems easier to confirm that good economic performance, in relative terms, may strengthen national identity than that poor economic performance 
will weaken national identity. Even if no definitive empirical evidence can be given at this point, our data suggest a rationalization or compensation mechanism such that citizens look for where to anchor their strong national identities after they have decided on them. If an economy is performing well in relative terms, then it would become a good anchorage for holding strong national identities. If an economy is performing poorly, then economic factors will cease to be a fundamental element for national identity holders. Citizens will then look for alternative anchorages of identity. This process could be facilitated by state elites that might point to which traits and characteristics are relevant in the given context. A further development of the findings in this article should be put in relation to our findings regarding the role played by political elites in different countries in a two-fold sense: first, regarding how the economic performance of the country is characterized (in relative terms overall), and, second, in relation to the anchorage that is mentioned in relation to the meaning of national identity.

Author Contributions: Conceptualization, methodology, data curation, analysis, writing-original draft preparation, writing — review and editing, A.M.R.J., N.A.L. and E.F.F. All authors have read and agreed to the published version of the manuscript.

Funding: This research received no external funding.

Institutional Review Board Statement: Ethical review and approval were waived for this study, due to the use of, already published, secondary quantitative anonymized data alone.

Informed Consent Statement: Not applicable.

Data Availability Statement: The data presented in this study are openly available in GESIS Leibniz Instite for the Social Science, at doi: 10.4232/1.10950 (EB57.2, reference number ZA3640), doi: 10.4232/1.10974 (EB65.2, reference number ZA4506), doi: 10.4232/1.11430 (EB73.3, reference number ZA5233), doi: 10.4232/1.12050 (EB77.3, reference number ZA5612). Other data is contained within the article's Appendix A.

Conflicts of Interest: The authors declare no conflict of interest.

Appendix A

\begin{tabular}{|c|c|c|c|c|c|c|c|c|c|}
\hline Country & Year & $\begin{array}{c}\text { Very_- } \\
\text { Attached }\end{array}$ & $\begin{array}{c}\text { Fairly_ } \\
\text { Attached }\end{array}$ & $\begin{array}{c}\text { Total_ } \\
\text { Attached }\end{array}$ & $\begin{array}{c}\text { Gdp_ } \\
\text { ppp }\end{array}$ & $\%$ GDP & GINI & Paro\%Activa & Sstran \\
\hline GERMANY & 2000 & 33 & 52 & 85 & 26.6 & 3.0 & & 7.7 & \\
\hline GERMANY & 2002 & 41 & 48 & 89 & 28.4 & 0.0 & & 8.6 & \\
\hline GERMANY & 2003 & 38 & 48 & 86 & 29.3 & -0.7 & & 9.3 & \\
\hline GERMANY & 2004 & 41 & 47 & 88 & 30.6 & 1.2 & & 10.3 & 18.1 \\
\hline GERMANY & 2005 & 38 & 49 & 87 & 32.1 & 0.7 & & 11.1 & 17.9 \\
\hline GERMANY & 2006 & 41 & 47 & 88 & 34.6 & 3.7 & 32.8 & 10.3 & 17.1 \\
\hline GERMANY & 2007 & 43 & 47 & 90 & 36.7 & 3.3 & 32.4 & 8.6 & 16.0 \\
\hline GERMANY & 2010 & & & & 39.6 & 4.1 & 31.1 & 7.1 & 16.7 \\
\hline GERMANY & 2012 & 50 & 43 & 93 & 43.6 & 0.4 & 30.1 & 5.4 & 15.6 \\
\hline SPAIN & 2000 & 58 & 33 & 91 & 21.8 & 5.3 & & 14.2 & \\
\hline SPAIN & 2002 & 39 & 41 & 80 & 24.6 & 2.9 & & 11.6 & \\
\hline SPAIN & 2003 & 56 & 36 & 92 & 25.3 & 3.2 & & 11.5 & \\
\hline SPAIN & 2004 & 59 & 31 & 90 & 26.4 & 3.2 & 33.4 & 11.2 & 11.6 \\
\hline SPAIN & 2005 & 53 & 36 & 89 & 27.8 & 3.7 & 32.5 & 9.3 & 11.5 \\
\hline SPAIN & 2006 & 52 & 36 & 88 & 30.8 & 4.2 & 32.7 & 8.6 & 11.3 \\
\hline SPAIN & 2007 & 50 & 42 & 92 & 32.8 & 3.8 & 33.9 & 8.4 & 11.5 \\
\hline SPAIN & 2010 & & & & 32.3 & 0.0 & 35.8 & 20.2 & 15.1 \\
\hline SPAIN & 2012 & 49 & 36 & 85 & 32.2 & -2.6 & 35.9 & 25.2 & 16.2 \\
\hline GREECE & 2000 & 79 & 15 & 94 & 19.3 & 4.2 & & 11.1 & \\
\hline GREECE & 2002 & 77 & 19 & 96 & 22.7 & 3.9 & & 10.3 & \\
\hline GREECE & 2003 & 88 & 10 & 98 & 23.8 & 5.8 & & 9.7 & \\
\hline
\end{tabular}




\begin{tabular}{|c|c|c|c|c|c|c|c|c|c|}
\hline Country & Year & $\begin{array}{c}\text { Very_- } \\
\text { Attached }\end{array}$ & $\begin{array}{c}\text { Fairly_ } \\
\text { Attached }\end{array}$ & $\begin{array}{c}\text { Total_ } \\
\text { Attached }\end{array}$ & $\begin{array}{l}\text { Gdp_- } \\
\text { ppp }\end{array}$ & $\%$ GDP & GINI & Paro\%Activa & Sstran \\
\hline GREECE & 2004 & 84 & 13 & 97 & 25.4 & 5.1 & 34 & 10.5 & 12.8 \\
\hline GREECE & 2005 & 78 & 19 & 97 & 25.3 & 0.6 & 35.1 & 9.8 & 13.6 \\
\hline GREECE & 2006 & 83 & 15 & 98 & 28.2 & 5.7 & 35.4 & 8.9 & 14.0 \\
\hline GREECE & 2007 & 76 & 21 & 97 & 29.3 & 3.3 & 34.6 & 8.3 & 14.6 \\
\hline GREECE & 2010 & & & & 28.9 & -5.5 & 34.5 & 12.5 & 17.7 \\
\hline GREECE & 2012 & 79 & 20 & 99 & 25.9 & -7.3 & 36.7 & 24.2 & 20.3 \\
\hline ITALY & 2000 & 48 & 43 & 91 & 26.6 & 3.7 & & 10.8 & \\
\hline ITALY & 2002 & 58 & 36 & 94 & 27.9 & 0.3 & & 9.2 & \\
\hline ITALY & 2003 & 56 & 41 & 97 & 28.4 & 0.2 & & 8.9 & \\
\hline ITALY & 2004 & 56 & 39 & 95 & 28.7 & 1.6 & 34.5 & 7.9 & 16.2 \\
\hline ITALY & 2005 & 53 & 39 & 92 & 29.6 & 0.9 & 34.1 & 7.7 & 16.3 \\
\hline ITALY & 2006 & 44 & 45 & 89 & 31.9 & 2.0 & 34.3 & 6.8 & 16.3 \\
\hline ITALY & 2007 & 50 & 41 & 91 & 33.7 & 1.5 & 33.2 & 6.1 & 16.4 \\
\hline ITALY & 2010 & & & & 34.7 & 1.7 & 34.4 & 8.4 & 18.6 \\
\hline ITALY & 2012 & 41 & 46 & 87 & 35.9 & -2.8 & 35.2 & 10.7 & 19.3 \\
\hline PORTUGAL & 2000 & 60 & 36 & 96 & 17.8 & 3.8 & & 3.9 & \\
\hline PORTUGAL & 2002 & 61 & 36 & 97 & 19.3 & 0.8 & & 5.0 & \\
\hline PORTUGAL & 2003 & 62 & 35 & 97 & 19.8 & -0.9 & & 6.3 & \\
\hline PORTUGAL & 2004 & 70 & 26 & 96 & 20.2 & 1.8 & 38.9 & 6.7 & 13.5 \\
\hline PORTUGAL & 2005 & 65 & 31 & 96 & 22.0 & 0.8 & 38.5 & 7.6 & 14.0 \\
\hline PORTUGAL & 2006 & 71 & 26 & 97 & 23.8 & 1.6 & 38.1 & 7.7 & 14.1 \\
\hline PORTUGAL & 2007 & 42 & 52 & 94 & 25.2 & 2.5 & 36.8 & 8.0 & 14.1 \\
\hline PORTUGAL & 2010 & & & & 26.9 & 1.9 & 35.8 & 10.8 & 16.4 \\
\hline PORTUGAL & 2012 & 54 & 40 & 94 & 27.1 & -4.0 & 36 & 15.6 & 17.6 \\
\hline
\end{tabular}

\section{References}

Alba, Richard D. 1990. Ethnic Identity: The Transforamtion of White America. New Haven: Yale University Press.

Alba, Richard D., and Victor Nee. 2003. Remaking the American Mainstream: Assimilation and Contemporary Immigration. Cambridge: Harvard University Press.

Andersen, Robert, and Tina Fetner. 2008. Economic inequality and intolerance: Attitudes toward homosexuality in 35 democracies. American Journal of Political Science 52: 942-58. [CrossRef]

Armingeon, Klaus, and Kai Guthmann. 2014. Democracy in crisis? The declining support for national democracy in European countries, 2007-11. European Journal of Political Research 53: 423-42. [CrossRef]

Arzheimer, Kai. 2015. The AfD: Finally a Successful Right-Wing Populist Eurosceptic Party for Germany? West European Politics 38: 535-56. [CrossRef]

Baldini, Gianfranco. 2013. Don't Count Your Chickens before They're Hatched: The 2013 Italian Parliamentary and Presidential Elections. South European Society and Politics 18: 473-97. [CrossRef]

Béland, Daniel, Alistair Cole, Régis Dandoy, Pierre Baudewyns, Valeria Fargion, Maurizio Ferrera, and Joan Subirats. 2005. The Territorial Politics of Welfare. Edited by McEwen Nicola and Luis Moreno. London: Routledge.

Bordignon, Fabio, and Luigi Ceccarini. 2013. Five Stars and a Cricket. Beppe Grillo Shakes Italian Politics. South European Society and Politics 18: 427-49. [CrossRef]

Braun, Dietmar, and Philipp Trein. 2014. Federal dynamics in times of economic and financial crisis. European Journal of Political Research 53: 803-21. [CrossRef]

Brown, David. 1998. Why is the Nation-State so Vulnerable to Ethnic Nationalism? Nations and Nationalism 4: 1-15. [CrossRef]

Brubaker, Rogers. 1992. Citizenship and Nationhood in France and Germany. Cambridge: Harvard University Press.

Brubaker, Rogers. 2011. Economic crisis, nationalism and Politicezed Ethnicity. In The Deepening Crisis. Governance Challenges after Neoliberalism. Edited by G. Derluguian and C. Calhoun. New York: New York University Press, pp. 93-109.

Campbell, John L., and John A. Hall. 2009. National identity and the political economy of small states. Review of International Political Economy 16: 547-72. [CrossRef]

Chao, Ruth K., and Michiko Otsuki-Clutter. 2011. Racial and ethnic differences: Sociolcultural and contextual explanations. Journal of Research on Adolescence 21: 47-60. [CrossRef]

Citrin, Jack, and Donald P. Green. 1990. The self-interest motive in American public opinion. In Research in Micropolitics. Edited by Long Samuel. Greenwhich: JAI Press.

Cordero, Guillermo, and José Ramón Montero. 2015. Against Bipartyism, Towards Dealignment? The 2014 European Election in Spain. South European Society and Politics 20: 357-79. [CrossRef]

Cox, Trevor F., and Michael A. A. Cox. 2001. Multidimensional Scaling, 2nd ed. Boca Raton: Chapmand and Hall/CRC. 
Crane, George T. 1998. Economic Nationalism: Bringing the Nation Back In. Millennium-Journal of International Studies 27: 55-75. [CrossRef]

Danigelis, Nicholas L., Melissa Hardy, and Stephen J. Cutler. 2007. Population aging, intracohort aging, and sociopoliticcal attitudes. American Sociological Review 72: 812-30. [CrossRef]

Deutsch, Karl W. 1964. The Price of Integration. In The Integration of Political Communities. Edited by P. E. Jacob and J. V. Toscano. Philadelphia: Lippincott, pp. 143-78.

Dotti Sani, Giulia M., and Beatrice Magistro. 2016. Increasingly unequal? The economic crisis, social inequalities and trust in the European Parliament in 20 European countries. European Journal of Political Research 55: 246-64. [CrossRef]

Eisenstadt, Shmuel Noah, and Bernhard Giesen. 1995. The construction of collective identity. European Journal of Sociology 36: 72-102. [CrossRef]

Fernandes, Jorge M. 2016. The seeds for party system change? The 2015 Portuguese general election. West European Politics 39: 890-900. [CrossRef]

Freire, André, Marco Lisi, Ioannis Andreadis, and José Manuel Leite Viegas. 2014. Political Representation in Bailed-out Southern Europe: Greece and Portugal Compared. South European Society and Politics 19: 413-33. [CrossRef]

Green, Donald, Bradley Palmquist, and Eric Cchickler. 2002. Partisan Hearts and Minds: Political Parties and the Social Identities of Voters. New Haven: Yale University Press.

Greenfeld, Liah, and Daniel Chirot. 2014. Nationalism and aggression. Theory and Society 23: 79-103. [CrossRef]

Guglielmi, Simona, and Cristiano Vezzoni. 2016. Meanings of National and European Identities. In European Identity in the Context of National Identity. Edited by B. Westle and P. Segatti. Oxford: Oxford University Press, pp. 140-64.

Hadler, Markus, Kiyoteru Tsutsui, and Lynn G. Chin. 2012. Conflicting and Reinforcing Identities in Expanding Europe: Individualand Country-Level Factors Shaping National and European Identities, 1995-2003. Sociological Forum 27: 392-418. [CrossRef]

Hernández, Enrique, and Hanspeter Kriesi. 2016. The electoral consequences of the financial and economic crisis in Europe. European Journal of Political Research 55: 203-24. [CrossRef]

Hettne, Björn. 1993. Ethnicity and development-An elusive relationship. Contemporary South Asia 2: 123-49. [CrossRef]

Hobolt, Sara B., and James Tilley. 2016. Fleeing the centre: the rise of challenger parties in the aftermath of the euro crisis. West European Politics 39: 971-91. [CrossRef]

Huddy, Leoni. 2013. From group identity to political cohesion and commitment. In The Oxford Handbook of Politcal Psychology. Edited by Huddy Leoni, David O. Sears and Jack S. Levy. Oxford: Oxford University Press, pp. 737-73.

Irsenia, Pierangelo, Irena Fikey, Fabio Serricchio, and Bettina Westle. 2012. But still it does not move: Functional and identity-based determinants of European identity. In Citizens and the European Polity: Mass Atttudes towards the European and National Polities. Edited by Sanders David, Pedro Magalhaes and Gabor Tóka. Oxford: Oxford University Press, pp. 110-39.

Jalali, Carlos. 2012. The 2011 Portuguese Presidential Elections: Incumbency Advantage in Semi-presidentialism? South European Society and Politics 17: 239-60. [CrossRef]

Jones, Frank L., and Philip Smith. 2001. Diversity and commonality in national identities: An exploratory analysis of cross-national patterns. Journal of Sociology 37: 45-63. [CrossRef]

Katz, Phyllis A., and Jennifer A. Kofkin. 1997. Race, gender and young children. In Developmental Psychopathology: Perspectives on Adjustment, Risk, and Disorder. Edited by Luthar Suniya, Jacop Burak, Dante Cicchetti and John R. Weisz. New York: Cambridge University Press, pp. 51-74.

Keating, Michael. 2001. Nations Against the State. The New Politics of Nationalism in Quebec, Catalonia and Scotland. New York: MacMillan Press. [CrossRef]

Kriesi, Hanspeter. 2012. The political consequences of the financial and economic crisis in Europe: Electoral punishment and popular protest. Swiss Political Science Review 18: 518-22. [CrossRef]

Kriesi, Hanspeter. 2014. The Populist Challenge. West European Politics 37: 361-78. [CrossRef]

Mackie, J. L. 1965. Causes and Conditions. American Philosophical Quarterly 2: 245-64.

Maiz, Ramón. 2003. Framing the nation: Three rival versions of contemporary nationalist ideology. Journal of Political Ideologies 8: 251-67. [CrossRef]

Mason, Andrew. 2010. Integration, Cohesion and National Identity: Theoretical Reflections on Recent British Policy. British Journal of Political Science 40: 857-74. [CrossRef]

McEwen, Nicola. 2006. Nationalism and the State. Brussels: P.I.E.-Peter Lang.

Miller, David. 2000. Citizenship and National Identity. Cambridge: Cambridge University Press.

Phinney, Jean S. 1990. Ethnic identity in adolescents and adults: Reviw of research. Psychological Bulletin 108: 499-514. [CrossRef]

Quintana, Stephen M. 2007. Racial and ethnic identity: Developmental perspectives and research. Journal of Counseling Psychology 54: 259-70. [CrossRef]

Rodríguez-Pose, Andrés, and Richard Sandall. 2008. From identity to the economy: Analysing the evolution of the decentralisation discourse. Environment and Planning C: Government and Policy 26: 54-72. [CrossRef]

Ruiz Jiménez, Aantonia María. 2007. Los instrumentos de medida de las identidades en los estudios del CIS y el Eurobarómetro: Problemas de la escala Moreno y posibles alternativas. Revista Española de Investigaciones Sociológicas 117: 161-82. [CrossRef]

Ruiz Jiménez, Antonia María, José Manuel Echavarren Fernández, and Nieves Aquino Llinares. 2018. Gone with the crisis? A multilevel analysis of economy, welfare and attachment to the nation in Europe. Análise Social 53: 928-56. [CrossRef] 
Schumacher, Gijs, and Kees van Kersbergen. 2016. Do mainstream parties adapt to the welfare chauvinism of populist parties? Party Politics 22: 300-12. [CrossRef]

Sears, David O., and Cristia Brown. 2013. Childhood and adult political development. In The Oxford Handbook of Politcal Psychology. Edited by L. Huddy, D. O. Sears and J. S. Levy. Oxford: Oxford University Press, pp. 59-95.

Sears, David O., and Carolyn L. Funk. 1999. Evidence of the Long-Term Persistence of Adults' Political Predispositions. The Journal of Politics 61: 1-28. [CrossRef]

Sears, David O., and Carolyn L. Funk. 1991. The role os self-interest in social and political attitudes. Advances in Experimental Social Psychology 24: 1-91. [CrossRef]

Shayo, Moses. 2009. A Model of Social Identity with an Application to Political Economy: Nation, Class, and Redistribution. American Political Science Review 103: 147-74. [CrossRef]

Shulman, Stephen. 2002. Challenging the civic/ethnic and West/East dichotomies in the study of nationalism. Comparative Political Studies 35: 554-85. [CrossRef]

Shulman, Stephen. 2003. Exploring the economic basis of nationhood. Nationalism and Ethnic Politics 9: 23-49. [CrossRef]

Smith, Anthony. 1991. National identity. London: Penguin Books.

Solt, Frederik. 2011. Diversionary Nationalism: Economic Inequality and the Formation of National Pride. The Journal of Politics 73: 821-30. [CrossRef]

Stoker, Laura, and M. Kent Jennings. 2008. Of time and the development of partisan polarization. American Journal of Political Science 52: 619-35. [CrossRef]

Vasilopoulou, Sofia, and Daphne Halikiopoulou. 2013. In the Shadow of Grexit: The Greek Election of 17 June 2012. South European Society and Politics 18: 523-42. [CrossRef]

Wright, Matthew. 2011. Diversity and the imagined community: Immigrant diversity and conceptions of national identity. Political Psychology 32: 837-62. [CrossRef] 